\title{
How to Avoid "Unenlightened Sorrow": A Statistical Analysis of Plain Remarriage
}

\author{
Ben Wesley Beachy \\ Graduate Student \\ Kent State University \\ beachy.55@osu.edu
}

\begin{abstract}
This article is a basic quantitative analysis of widowhood and remarriage trends among several Plain churches. When compared to past studies of similar topics, a remarkable consistency of findings across both time and sect can be identified. Bereaved Plain spouses have largely experienced widowhood along separate gender-specific paths, in data sets ranging from 1730 to 2019 and from relatively liberal to traditional communities. Positing that much of Amish and Amish Mennonite society is designed to socialize and retain children, this article offers opportunities for deeper study of the parental roles undergirding that society. The primary research suggestions include spousal function in the context of family life, the various factors influencing the health of bereaved spouses, and the "marriage squeeze" present in many churches. The central data sets used in this study were collected from the 2019 edition of the Amish Mennonite Directory and the 2015 Church Directory of the Lancaster County Amish and Outlying Daughter Settlements. These reference books were sampled on a one-in-five and one-in-three basis, respectively. The resultant widowhood cases were contextualized by widowhood cases from studies by Elmer Lewis Smith and researchers at the University of Maryland School of Medicine.
\end{abstract}

Submitted April 30, 2021; accepted August 21, 2021; published October 8, 2021

https://doi.org/10.18061/jpac.v2i1.8292

Keywords: demography, widowhood, bereavement effect, social change

\section{Introduction}

The centrality of family life is a common refrain in Anabaptist studies. ${ }^{1}$ Reflecting the structure and hierarchy of the church, Plain church family life is designed, in part, to socialize and retain children. Children are constantly exposed to examples of how to perform the gendered expectations of their sex - with women running the domestic side of the home and men working to provide that home's economic stability — as well as older relatives who can serve as examples of a Plain life well-lived.

A wealth of scholarship has depicted this model for Anabaptist family life and its purported benefits. ${ }^{2}$ However, these analyses of Amish and Mennonite social successes often leave an important question unaddressed. With a focus on the kitchen and the home, what happens when a

\footnotetext{
${ }^{1}$ Schmidt, Zimmerman Umble, and Reschly, Strangers at Home; Kraybill, Riddle of Amish Culture; Hostetler, Amish Roots.

${ }^{2}$ Hurst and McConnell, Amish Paradox; Kraybill, Riddle of Amish Culture; Stevenson, Everson, and Crawford, "Family Size and Reproductive Span"; Schmidt, Zimmerman Umble, and Reschly, Strangers at Home.
} 
wife passes and those domains lose their biblically ordained helpmeet? Likewise, what happens when a husband's loss takes away the family's source of income and labor?

Much existent commentary concerns the challenges to Amish attitudes in situations of remarriage and single parenthood. ${ }^{3}$ But a new quantitative review of widowhood can inform our understanding of those attitudes and contribute to our conception of Plain Anabaptist social ties. One ethnographic work on the Old Order Amish outlines a conception of mourning, which the author describes as avoiding any sense of "unenlightened sorrow." ${ }^{4}$ While this could seem callous from the perspective of an outsider, considering that approach alongside this article's demographic data provides opportunities for deeper study of Amish family life.

This article provides a basic statistical analysis of widowhood and remarriage in some Amish Mennonite and Old Order communities. By comparing that data to past studies on similar topics, it also identifies trends that have persisted in the face of other social change. Amish and Amish Mennonite gender roles function within social and historical context. Investigating the remarkable consistency of the widowhood experience is one way to better understand that context.

Any current discussion of Plain gender conventions is well-timed, in light of recent publications by Karen Johnson-Wiener and The Journal of Amish and Plain Anabaptist Studies. ${ }^{5}$ These writings portray a similar state of widowhood to those described by past scholars such as Schreiber and Smith: widowers tend to remarry single women within a few years of their wife's passing, while widows often carry on alone and refrain from pursuing a second marriage. ${ }^{6}$ This disparity in remarriage rates is often internally attributed to biblical declarations on courtship, the fact that women outnumber men in most Amish communities because a greater share of women join the church, or the potential difficulty of blending families with numerous children. ${ }^{7}$ However, these reports do not fully explain the significant gendered differences in remarriage behavior.

A review of Amish Mennonite widowhood also inevitably addresses the bereavement process. Life course theory can provide context on the social transition process involved in losing a spouse. In a 1993 review of life transition research, Linda George described the social environments that are most conducive to comfortable life transitions. ${ }^{8}$ These environments feature economic and familial stability, relatively predictable life transition periods, and strong social networks encouraging the individual's socialization in a new role. ${ }^{9}$

On paper, it would appear that Amish and Amish Mennonite men and women are in a nearideal social environment for grieving the loss of a spouse. Plain homes tend to be quite stable, relative to the general American population. Similar family structure across generations can prevent life transition periods - such as the passing of a beloved spouse - from being jarring and

\footnotetext{
${ }^{3}$ Johnson-Weiner, Amish Women, 151-156; Hurst and McConnell, Amish Paradox, 129-131; Seifter et al., "Bereavement Effect."

${ }^{4}$ Kollmorgen, Contemporary Rural Community, 63.

5 Johnson-Weiner, Amish Women; Jellison, "Content Overview."

${ }^{6}$ Schreiber, Our Amish Neighbors, 39-40; Smith, The Amish Today.

${ }^{7}$ Johnson-Weiner, Amish Women, 154.

${ }^{8}$ George, "Sociological Perspectives on Life Transitions."

${ }^{9}$ George, "Sociological Perspectives on Life Transitions," 361-367.
} 
unpredictable. Additionally, newly bereaved Plain spouses usually have a social network of their peers willing to help them adjust to their new lives. This article considers whether Plain society is actually more conducive to healthy bereavement and avoiding the widowhood (or bereavement) effect, namely, the increased probability of a person dying relatively soon after their long-time spouse has died.

\section{Methods}

The demographic data analyzed in this article was compiled from recent household directories, primarily the 2019 edition of the Amish Mennonite Directory. Known colloquially as "The Red Book," this reference reports demographic information on most churches in the United States and Canada that "fit into a general description of "Amish Mennonites." ${ }^{10}$ Data on the 5,974 households listed includes dates of birth for all family members, marriage and remarriage dates, occupations, church memberships, and more. A one-in-five sampling from the Red Book rendered a data set of 1,306 households that included 108 spousal deaths and 57 remarriage cases. The second studied data set is the more geographically focused 2015 Church Directory of the Lancaster County Amish and Outlying Daughter Settlements (abbreviated as "2015 Greater Lancaster Old Order Amish" in data table headings). A one-in-three sampling from this resource included 105 cases of deaths and 25 remarriages in Old Order Amish homes. Studied together, these widowhood cases represent a significant window onto modern Amish and Amish Mennonite remarriage behaviors.

These contemporary Amish Mennonite and Old Order Amish data are contextualized by comparison to similar data from past studies of Amish widowhood. Quantitative findings referenced include Elmer Lewis Smith's work on Amish marriage cases from 1900-1955 ${ }^{11}$ and the work of Ari Seifter and colleagues using the University of Maryland School of Medicine's nearly two centuries of Amish marriage data, ${ }^{12}$ collected from the Anabaptist Genealogy Database. These studies provide family information from a more diverse range of Plain communities than the two directories above, as well as a longer time span, which informs the historical background of the data.

While this article's scope is quite narrow, these trends also require some context from the general American population. Predictably, non-Plain Americans experience remarriage at higher rates due to the availability of divorce. Nineteen percent of American women and 23 percent of American men above age 70 have married twice, while 8 percent of men and 6 percent of women have had a third spouse or more. ${ }^{13}$ Most notable is the parity between each gender's remarriage rates.

The primary drawback of this article's data is its lack of accompanying subjective and anecdotal information. Though only intended as a quantitative demographic review, this article does include some brief interpretation of the data presented. Restricted to the analysis and internal

\footnotetext{
${ }^{10}$ Miller and Miller, Amish Mennonite Directory, 10.

${ }^{11}$ Smith, The Amish Today, 206-208.

${ }^{12}$ Seifter et al., "Bereavement Effect."

${ }^{13}$ Gurrentz and Mayol-Garcia, "Love and Loss."
} 
Anabaptist commentary of other cited works, any conclusions from these data sets regarding familial gender roles would be limited. Scale also hampers these findings slightly, as the modern directories' widowhood cases combine for a total size of 82 . However, the sample sizes analyzed by Seifter et al. and Smith reach the thousands.

\section{Data and Results}

Following trends reported in past scholarship on Plain Anabaptists, remarriage appears to remain a disproportionately male practice. Overall remarriage rates can be found in Table 1.

Table 1

Remarriage Rates of Widow(er)s

\begin{tabular}{|c|c|c|c|c|c|c|c|c|c|c|c|c|}
\hline \multirow[b]{3}{*}{ Remarried? } & \multicolumn{12}{|c|}{2015 Greater Lancaster } \\
\hline & \multicolumn{2}{|c|}{ Widows } & \multicolumn{2}{|c|}{ Widowers } & \multicolumn{2}{|c|}{ Widows } & \multicolumn{2}{|c|}{ Widowers } & \multicolumn{2}{|c|}{ Widows } & \multicolumn{2}{|c|}{ Widowers } \\
\hline & $n$ & $\%$ & $n$ & $\%$ & $n$ & $\%$ & $n$ & $\%$ & $n$ & $\%$ & $n$ & $\%$ \\
\hline No & 73 & 91.3 & 87 & 63.8 & 62 & 98.4 & 27 & 52.9 & 1,863 & 91.2 & 1,280 & 66.4 \\
\hline Yes & 7 & 8.8 & 50 & 36.5 & 1 & 1.6 & 24 & 47.1 & 180 & 8.8 & 648 & 33.6 \\
\hline
\end{tabular}

Note. 1876-1900 data provided by Seifter et al.

There is a significant gendered disparity in remarriage after the death of a spouse, with consistently over 30 percent of Plain widowers remarrying compared to less than 10 percent of Plain widows. This disparity is attributed to several factors, including the overall gender imbalance in Amish and Mennonite populations, the cultural hurdles surviving wives face to pursue available men, ${ }^{14}$ and difficulty adjusting to new power dynamics in the home. ${ }^{15}$ The first of these factorssometimes referred to as the "marriage squeeze"-is likely the most salient noncultural factor, with some settlements reporting male-female ratios of around 1:1.65. ${ }^{16}$ Also notable is the consistency in remarriage rates across large time periods, with Seifter et al. at the University of Maryland reporting near-identical Amish figures to the centuries-later Amish Mennonite rates.

Plain widows who are able to remarry may do so with different motivations than their male counterparts, as evidenced by average ages at spouse death and remarriage. These statistics can be found in Tables 2 and 3 .

\footnotetext{
${ }^{14}$ Johnson-Weiner, Amish Women, 154.

${ }^{15}$ Smith, The Amish Today, 192.

${ }^{16}$ Johnson-Weiner, Amish Women, 138.
} 
Table 2

Age at Bereavement of Remarried Widow(er)s

\begin{tabular}{|c|c|c|c|c|c|c|c|c|}
\hline \multirow[b]{3}{*}{ Age } & \multicolumn{4}{|c|}{2019 Amish Mennonites } & \multicolumn{4}{|c|}{$\begin{array}{l}2015 \text { Greater Lancaster } \\
\text { Old Order Amish }\end{array}$} \\
\hline & \multicolumn{2}{|c|}{ Widows } & \multicolumn{2}{|c|}{ Widowers } & \multicolumn{2}{|c|}{ Widows } & \multicolumn{2}{|c|}{ Widowers } \\
\hline & $n$ & $\%$ & $n$ & $\%$ & $n$ & $\%$ & $n$ & $\%$ \\
\hline $20-29$ & 6 & 85.7 & 3 & 6.0 & 0 & 0.0 & 1 & 4.2 \\
\hline $30-39$ & 0 & 0.0 & 5 & 10.0 & 0 & 0.0 & 2 & 8.3 \\
\hline $40-49$ & 0 & 0.0 & 9 & 18.0 & 0 & 0.0 & 3 & 12.5 \\
\hline $50-59$ & 1 & 14.3 & 16 & 32.0 & 1 & 100.0 & 6 & 25.0 \\
\hline $60-69$ & 0 & 0.0 & 10 & 20.0 & 0 & 0.0 & 7 & 29.2 \\
\hline $70+$ & 0 & 0.0 & 7 & 14.0 & 0 & 0.0 & 5 & 20.8 \\
\hline $\begin{array}{c}\text { Average age at spouse's } \\
\text { death: remarried }\end{array}$ & \multicolumn{4}{|c|}{52.2} & \multicolumn{4}{|c|}{58.7} \\
\hline $\begin{array}{l}\text { Average age at spouse's } \\
\text { death: not remarried }\end{array}$ & \multicolumn{4}{|c|}{67.9} & \multicolumn{4}{|c|}{63.2} \\
\hline
\end{tabular}

Table 3

Age at Remarriage of Widow(er)s

\begin{tabular}{|c|c|c|c|c|c|c|c|c|}
\hline \multirow[b]{3}{*}{ Age } & \multicolumn{4}{|c|}{2019 Amish Mennonite } & \multicolumn{4}{|c|}{$\begin{array}{l}2015 \text { Greater Lancaster } \\
\text { Old Order Amish }\end{array}$} \\
\hline & \multicolumn{2}{|c|}{ Widows } & \multicolumn{2}{|c|}{ Widowers $^{a}$} & \multicolumn{2}{|c|}{ Widows } & \multicolumn{2}{|c|}{ Widowers } \\
\hline & $n$ & $\%$ & $n$ & $\%$ & $n$ & $\%$ & $n$ & $\%$ \\
\hline $20-29$ & 2 & 28.6 & 2 & 4.1 & 0 & 0.0 & 0 & 0.0 \\
\hline $30-39$ & 4 & 57.1 & 5 & 10.2 & 0 & 0.0 & 3 & 12.5 \\
\hline $40-49$ & 0 & 0.0 & 7 & 14.3 & 0 & 0.0 & 4 & 16.7 \\
\hline $50-59$ & 1 & 14.3 & 15 & 30.6 & 0 & 0.0 & 3 & 12.5 \\
\hline $60-69$ & 0 & 0.0 & 6 & 12.2 & 1 & 100.0 & 8 & 33.3 \\
\hline $70+$ & 0 & 0.0 & 14 & 28.6 & 0 & 0.0 & 6 & 25.0 \\
\hline $\begin{array}{l}\text { Average age at } \\
\text { remarriage }\end{array}$ & \multicolumn{4}{|c|}{54.8} & \multicolumn{4}{|c|}{59.5} \\
\hline
\end{tabular}

a One Amish Mennonite widower's remarriage date was not listed.

While the loss of a spouse can occur at any point across one's lifespan, only men seem to remarry across a similarly broad range of ages. Over 40 percent of remarried Amish Mennonite widowers found a wife after the age of 60 . By contrast, widows in the same population overwhelmingly remarried before the age of 40 . None remarried after the age of 54. Amish widows in the early twentieth century behaved similarly, with the typical second wedding occurring at the 
age of 38.8. ${ }^{17}$ Another Old Order data set from twentieth-century Lancaster County reported 44 percent of remarriages occurring when the bereaved spouse was between 40 and $55 .{ }^{18}$

This concentration of remarriages in younger widows is partially attributable to the aforementioned "marriage squeeze," a gender disparity that persists throughout old age. However, the general absence of late-life widow remarriages would suggest a more functional nature to those unions. Karen Johnson-Weiner describes two kinds of motivations for Anabaptist remarriage: those pursued for companionship and those pursued with a view to reconstituting a married household in which to raise children or have more children and thus tending to involve widows of child-bearing age. ${ }^{19}$ The 2019 and 1900-1955 data sets would suggest female remarriage is governed more by the latter pursuit.

This observation does not mean that family cohesion and child rearing are not also motivators for widowed men. Since the arrival of the Amish to America in the eighteenth century, average family size has been remarkably consistent. Both Amish and Amish Mennonite communities have reported roughly 5 children per family for over two centuries, though flocks of 10 to 12 are not uncommon. ${ }^{20}$ Conversely, remarriage cases from Amish Mennonite and Old Order data average 6.5 and 7.5 children, respectively.

Widowers also remarry with a sense of obligation for their children's futures. Typical is the comment of a man who remarried less than a year after his wife's passing and who said his children "needed a mother." 21 This sentiment is common in Plain communities, especially in affiliations that most heavily emphasize the centrality of home life and the kitchen.

The time gap between a spouse's death and remarriage is a useful tool for studying the influence of family size on remarriage behaviors. Tables 4 and 5 describe these periods of limbo and the effects of large families on newly single parents.

\section{Table 4}

Remarriage Waiting Period of Widow(er)s

\begin{tabular}{ccccc}
\hline & & & \multicolumn{2}{c}{$\begin{array}{c}\text { 2015 Greater Lancaster } \\
\text { Old Order Amish }\end{array}$} \\
\cline { 2 - 6 } $\begin{array}{c}\text { Years between spouse's } \\
\text { death and remarriage }\end{array}$ & $n$ & $\%$ & $n$ & $\%$ \\
\hline $0-1.49$ & 23 & 41 & 12 & 48 \\
$1.5-2.99$ & 15 & 27 & 6 & 24 \\
$3-4.49$ & 8 & 14 & 4 & 16 \\
$4.5+$ & 10 & 18 & 3 & 12 \\
\hline Average waiting time & & 3.2 & \multicolumn{3}{c}{2.2} \\
\hline
\end{tabular}

a One Amish Mennonite widower's remarriage date was not listed.

${ }^{17}$ Smith, The Amish Today, 207.

${ }^{18}$ Kozimor, "The Remarriage Interval."

${ }^{19}$ Johnson-Weiner, Amish Women, 154.

${ }^{20}$ Young Center, "Amish Population Profile, 2020"; Seifter et al., "Bereavement Effect."

${ }^{21}$ Johnson-Weiner, Amish Women, 154. 


\section{Table 5}

Remarriage Waiting Periods, Grouped by Family Size

\begin{tabular}{ccccc}
\hline & 2019 Amish Mennonite & a & $\begin{array}{c}\text { 2015 Greater Lancaster } \\
\text { Old Order Amish }\end{array}$ \\
\cline { 2 - 5 } Number of children & $n$ & $\begin{array}{c}\text { Avg. time between } \\
\text { spouse's death } \\
\text { and remarriage } \\
\text { (in years) }\end{array}$ & $\begin{array}{c}\text { Avg. time between } \\
\text { spouse's death } \\
\text { and remarriage } \\
\text { (in years) }\end{array}$ \\
\hline $0-3$ & 8 & 3.3 & 3 & 3.2 \\
$4-6$ & 19 & 2.6 & 10 & 2.5 \\
$7-9$ & 21 & 2.2 & 3 & 1.3 \\
$10+$ & 9 & 1.6 & 9 & 0.9 \\
\hline Average waiting time & \multicolumn{3}{c}{2.2} \\
\hline a One Amish Mennonite widower's remarriage date was not listed.
\end{tabular}

A significant majority of Amish and Amish Mennonite remarriages occurred within 24 months of a spouse's passing. One study of Lancaster County Old Order Amish cases from 1929 to 1988 found similar results, with 47 percent of remarriages occurring 8 to 17 months from the former spouse's passing. ${ }^{22}$ Some relatives find this relatively brief period to be jarring. One Old Order man reported waiting two years to remarry so as to avoid upsetting his grown children with a quick wedding. 23

Table 5 shows the decrease in average periods between marriages as family size increases. When a family included more children, the surviving spouse let less time pass before remarrying. Bereaved Amish Mennonite parents with more than 10 children rarely waited even 20 months on average.

These statistics are also interesting in the context of the bereavement effect-the rise in mortality among surviving spouses in the year after their partners' deaths - among the Amish. Seifter et al. report that in the first six months after an Amish spouse's death, the Amish survivors exhibit a lower bereavement effect relative to the non-Plain population in the same period, which is then followed by a significant increase compared to mainstream Americans. ${ }^{24}$ The authors hypothesize that the shared pressure of raising Amish children creates a uniquely close "attachment figure" bond between spouses, which could lead to increased mortality risk as a partner's absence weighs on the widowed spouse over time (beyond six months). Brief "wait times" before remarriages could be interpreted as supporting Seifter et al.'s theory of the attachment figure, as a sign that Amish spouses can bear an abbreviated grieving process for the sake of children, etc. The impact of remarriage and the bereavement effect on mortality will be discussed more thoroughly later in this article.

\footnotetext{
${ }^{22}$ Kozimor, "The Remarriage Interval."

${ }^{23}$ McCallister and Michael, "Old Order Amish Widowers."

${ }^{24}$ Seifter et al., "Bereavement Effect."
} 
These data sets provide hints on the motives behind Plain Anabaptist remarriages, but they also allow for a look at who is getting remarried. Information on spousal age gaps can be found in Tables 6 and 7.

\section{Table 6}

Age Gaps in First and Second Marriages

\begin{tabular}{|c|c|c|c|c|c|c|c|c|}
\hline \multirow{3}{*}{$\begin{array}{l}\text { Spousal age gap } \\
\text { (in years) }\end{array}$} & \multicolumn{4}{|c|}{2019 Amish Mennonite } & \multicolumn{4}{|c|}{$\begin{array}{l}2015 \text { Greater Lancaster } \\
\text { Old Order Amish }\end{array}$} \\
\hline & \multicolumn{2}{|c|}{ First marriage } & \multicolumn{2}{|c|}{ Second marriage } & \multicolumn{2}{|c|}{ First marriage } & \multicolumn{2}{|c|}{ Second marriage } \\
\hline & $n$ & $\%$ & $n$ & $\%$ & $n$ & $\%$ & $n$ & $\%$ \\
\hline $0-.99$ & 13 & 23 & 6 & 11 & 9 & 36 & 1 & 4 \\
\hline $1-2.99$ & 28 & 49 & 10 & 18 & 8 & 32 & 8 & 32 \\
\hline $3-4.99$ & 10 & 18 & 11 & 19 & 5 & 20 & 1 & 4 \\
\hline $5+$ & 6 & 11 & 30 & 53 & 3 & 12 & 15 & 60 \\
\hline Average age gap & \multicolumn{2}{|c|}{2.5} & \multicolumn{2}{|c|}{6.9} & \multicolumn{2}{|c|}{2.4} & \multicolumn{2}{|c|}{8.2} \\
\hline
\end{tabular}

Table 7

Remarriage Age Gaps, Grouped by Age at Bereavement

\begin{tabular}{cccccc}
\hline & \multicolumn{2}{c}{ 2019 Amish Mennonite } & \multicolumn{2}{c}{$\begin{array}{c}\text { 2015 Greater Lancaster } \\
\text { Old Order Amish }\end{array}$} \\
\cline { 2 - 6 } Age & $n$ & Avg. gap (in yrs) & \multicolumn{1}{c}{$n$} & Avg. gap (in yrs) \\
\hline $20-35$ & 11 & 3.4 & 1 & 5.7 \\
$36-50$ & 13 & 6.4 & 4 & 4.8 \\
$51-65$ & 19 & 8.6 & 11 & 6.1 \\
$66+$ & 14 & & 7.8 & 9 & 13.5 \\
\hline Average age gap & & 6.9 & & & 8.2 \\
\hline
\end{tabular}

The husband was the elder spouse in 72 percent of the recorded Amish Mennonite and Old Order Amish marriages. First marriage age gaps rarely exceed five years, with nearly three quarters of couples being separated by less than three years. Second marriage age gaps tend to be five to six years larger. This is unsurprising, especially as widowers seem often to remarry women young enough to continue bearing and raising children. The largest second marriage age gap in the 2019 Lancaster Old Order Amish directory data was 25.2 years, from a marriage between a widower who was 72 years of age and a single woman who was 47 . Conversely, the largest gap produced by a remarrying widow was 1.8 years. This disparity is also reflected in the oldest remarriage cases for each gender - the oldest bereaved man to remarry was 81 , while the oldest remarrying widow was 54 . Table 7 depicts the general widening of age gaps as widowers grow older. 
Small age gaps between Plain husbands and wives are largely the result of the young ages at which they tend marry. Elmer Lewis Smith reported in 1961 that Amish women who failed to marry by age 23 often remained single for life, unless they married a bereaved husband. ${ }^{25}$ A less stark version of this assessment is reflected in Table 8, which shows first marriage ages from the 2019 edition of the Amish Mennonite Directory.

Table 8

Age at First Marriage

\begin{tabular}{cccc}
\hline & \multicolumn{3}{c}{ 2019 Amish Mennonite } \\
\cline { 2 - 4 } Age & Males (\%) & Females (\%) & Overall (\%) \\
\hline 17 & .3 & 1.5 & .9 \\
18 & 1.2 & 3.7 & 2.5 \\
19 & 4.0 & 9.1 & 6.6 \\
20 & 10.7 & 18.3 & 14.5 \\
21 & 17.8 & 16.8 & 17.3 \\
22 & 16.0 & 11.9 & 13.9 \\
23 & 13.5 & 10.9 & 12.2 \\
24 & 8.9 & 7.0 & 8.0 \\
25 & 6.2 & 5.1 & 5.6 \\
26 & 5.8 & 3.9 & 4.8 \\
27 & 3.9 & 3.0 & 3.4 \\
28 & 3.2 & 3.0 & 3.1 \\
29 & 2.2 & 1.5 & 1.8 \\
$30-47$ & 6.4 & 5.1 & 5.8 \\
\hline
\end{tabular}

While the window for marriage is slightly wider than it was six decades ago, roughly twice as many Plain women marry at 20 and 21 than between 24 and 27. The likelihood of marriage now appears to drop sharply around age 26 for women and men alike. In this context, it is hardly surprising that widowers usually have a plethora of choices when deciding to find a second wife. Teenage girls in some settlements can expect to be single throughout their young adult lives, and perhaps beyond, due to gender disparities and the relatively slim opportunities for marriages. ${ }^{26}$

With some Amish and Amish Mennonite women unable to attain the socially validated goal of marriage, which is necessary for full participation in church life, many single women might hope to become a widower's second wife. ${ }^{27}$ Table 9 includes the rates at which widowers remarry single or widowed women.

\footnotetext{
${ }^{25}$ Smith, The Amish Today, 207.

${ }^{26}$ Johnson-Weiner, Amish Women, 138.

${ }^{27}$ Johnson-Weiner, Amish Women, 155.
} 


\section{Table 9}

Premarital Status of Second Spouses

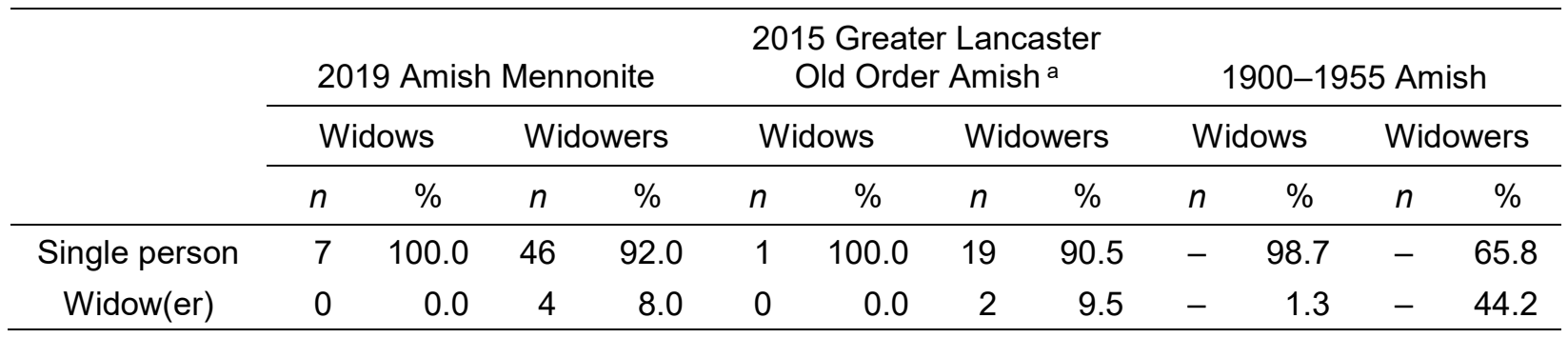

Note. 1900-1955 data provided by Elmer Lewis Smith.

a The premarital status of three Old Order Amish women who married widowers was not listed.

Single women do seem to dominate the pool of available choices for widowed fathers, with data sets reporting that roughly 65-90 percent of second marriages involve a previously unwed woman. These women come without the perceived challenges of integrating two sets of children, acclimating to a different spousal power dynamic, and expanding extended family networks. Conversely, some Amish widowers may feel that only a widow could understand their state of mind and the challenges of raising children who have lost a parent. ${ }^{28}$ These cases are nevertheless somewhat rare.

In his study of early twentieth-century Amish marriages, Elmer Lewis Smith wrote that 31 percent of second marriages occurred outside the traditional winter "wedding season." These outliers, comprising one of every four out-of-season marriages at the time, were interpreted as a sign of second marriages' lesser social importance than those between young people. As they were held with less ceremony and celebration, remarriages could fit into busier times of the year. ${ }^{29}$ This trend was reflected in remarriage dates from the 2015 and 2019 directories. However, with a more general Amish abandonment of the traditional late fall and winter months for weddings, ${ }^{30}$ these dates are no longer outliers. Nearly half to two-thirds of second weddings now occur outside the November-February window, designated in Table 10 as "in season." They also comprise a much smaller portion of total out-of-season marriages than the previous 25 percent. This trend is possibly attributable to a combination of the wedding shift and the lesser prestige of second weddings.

\footnotetext{
${ }^{28}$ Johnson-Weiner, Amish Women, 155.

${ }^{29}$ Smith, The Amish Today, 108-109.

${ }^{30}$ Troyer, "Change and Continuity in Amish Wedding Dates."
} 
Table 10

Seasonal Timing of Second Marriages

\begin{tabular}{lccc}
\hline & 2019 Amish Mennonite & $\begin{array}{c}\text { 2015 Greater Lancaster } \\
\text { Old Order Amish }\end{array}$ & 1900-1955 Amish \\
Remarriage timing & $\%$ & 39 & 69 \\
\hline "In season" & 52 & 61 & 31 \\
"Out of season" & 48 & - & 25 \\
\% of total "out of & 4 & & 25 \\
season" marriages & & & \\
\hline
\end{tabular}

Note: 1900-1955 data provided by Elmer Lewis Smith.

\section{Discussion}

The findings are not revolutionary, but they are significant in corroborating past quantitative studies of marriage and widowhood and their accompanying commentary.

The value in these analyses lies in their contribution to emergent discussions on the socially constructed nature of Plain gender roles ${ }^{31}$ and the centrality of women in those communities. ${ }^{32}$ Much recent research brought more nuance to external views of the lives of Amish women and men. This work has often focused on women as agents of change, whether social or economic. ${ }^{33}$ Yet despite the shifts at all levels of Amish and Amish Mennonite life in the past century, informal conventions about widowhood and remarriage appear to have remained firm. Expectations about who is to remarry and who is to carry on alone are as unflinching as the general expectation to wed, and to bear and socialize Amish children.

One takeaway from this data could be an emphasis on the remarkable level of submission to social norms still present in Plain communities. Seifter et al.'s concept of the attachment figure was discussed previously. ${ }^{34}$ Though this concept is not unique to Anabaptist studies, those authors consider the phenomenon it represents to be especially prevalent among the Amish populations they studied. They argue that the shared imperative to raise Amish children and the knowledge that their marriage will last until death likely bonds couples especially closely. Seifter et al. credit this concept for the high mortality rate among Amish spouses who lost their partner more than six months prior.

This perhaps unique bond may seem counterintuitive when set against the otherwise brief periods between spousal death and widower remarriage. The Plain grieving process is admittedly more subdued than in the general population, but the intermissions of only six to twelve months common among widowed men still raise questions about the credibility of the study's assertion on the prominence of the "attachment figure" phenomenon among Amish couples. One possible

\footnotetext{
${ }^{31}$ Jolly, "Hemmed In."

${ }^{32}$ Johnson-Weiner, Amish Women; Handrick, "Work and Change."

${ }^{33}$ Handrick, "Work and Change"; Graybill, "Amish Women, Business Sense"; Johnson-Weiner, Amish Women, 19-26.

${ }^{34}$ Seifter et al., "Bereavement Effect."
} 
explanation is Amish people's resignation to expectations of family cohesion and home stability. In fully submitting to God and giving up individual anguish, the Amish parent may be able to overlook that emotion and remarry for the sake of their children. Data reported by Kozimor also suggests that home stability could motivate remarriages. ${ }^{35}$ In Lancaster County Old Order Amish cases from 1929 to 1988, bereaved spouses with children younger than 9 were 35 percent more likely to remarry within 17 months than those with adult children. Conversely, spouses with adult children were 28.9 percent more likely to remarry after 37 months.

This explanation does not imply that Plain gender roles are so internalized as to fully determine personal choices. Natalie Jolly describes a spectrum of choice available to Plain women, of which they are acutely aware. This spectrum ranges from submission to autonomy, from community to individuality, and from self-denial to pride. While women in conservative communities are more restricted in finding their own balance on that scale, they understand that personal choices (and their social consequences) exist. ${ }^{36}$

At significantly higher rates than their male counterparts, young Amish women choose the church's side of that spectrum and remain through adulthood. They choose to remain in a community that requires them to marry to achieve full recognition, ${ }^{37}$ even though some know that young men leaving the church leads to the "marriage squeeze." Coupled with familial pressure to stay in the church, the idea that a single woman is incapable of being self-sufficient in the outside world could contribute to this phenomenon. It would be unrealistic to argue that so many Amish women stay Amish solely because they feel trapped. So what compels them to choose community over more autonomy?

The pervasive, everyday practices in Plain society, especially in Old Order Amish communities, facilitate the socialization and retention of children. Cultural isolation, parochial schooling, economic self-sufficiency, and mutual aid programs all promote baptism and confront the issues that could otherwise lead to young people leaving the community. However, the most salient aspect of socializing children is certainly home life.

The home is the center of Amish society. ${ }^{38}$ Many of the most important events in an Amish life will occur there. The home is also a priceless space for childhood development. John A. Hostetler described the home as a space designed to train Amish children for adult life. ${ }^{39}$ One Amish man emphasized the importance of learning obedience in the home, preparing children for life in the greater community. ${ }^{40}$ Findings from Indiana show that Amish parents who send their children to public school rely on strong home environments to counter contact with mainstream culture. ${ }^{41}$

\footnotetext{
${ }^{35}$ Kozimor, "The Remarriage Interval."

${ }^{36}$ Jolly, "Hemmed In."

${ }^{37}$ Community reports from periodicals, especially The Budget, often describe settlements as being composed of a certain number of families and a certain number of widows, even if those widows have unmarried children.

${ }^{38}$ Smith, The Amish Today, 137.

${ }^{39}$ Hostetler, Amish Society, 155-60.

${ }^{40}$ Johnson-Weiner, Amish Women, 35.

${ }^{41}$ Thalheimer, "A Little More in the World."
} 
Inside the house is where the earliest and most crucial Plain socialization occurs, especially for young girls learning to look forward to a large family of their own. This concept is manifested most fully by those families that also house grandparents on the same property, allowing children to see the rewards of church membership across a wide age span.

What happens, then, when the helm of the home and kitchen disappears? What happens when the figure organizing this crucial center of Plain life passes, and the working husband loses the helpmeet assigned to run the home for which he provides stability? In this social context, the gendered split on remarriage can be seen in a new light.

Looking at the remarriage data alone, Amish and Amish Mennonite women might appear replaceable. When a wife passes with children in the home and the bereaved husband seeks to remarry, he has a ready pool of candidates and often seems to make a choice with haste. Conversely, men seem much less replaceable. Even considering the lack of agency provided to women seeking a spouse, the fact that over 90 percent of widows remain single could suggest that the original husband's role in the family is too significant to be filled by anyone else.

It could be argued that the inverse is true. From a highly functional and socialization-focused standpoint, the roles of Plain spouses in family life are straightforward. Wives raise obedient children who are ready to accept church authority and raise their own families, while husbands provide the order and economic stability required for his partner's duties. These descriptions are oversimplified, but they describe the basic parental work shared in Plain homes. Judging by remarriage rates and average waiting periods, the truly irreplaceable presence in the Plain family dynamic is the wife and mother. Without a helpmeet to realize the labor provided by the father, the home is left without a rudder. There is no external presence that can make up for the very real domestic work provided by the Amish or Amish Mennonite woman - that role requires a human in the home. The same does not appear to be true in homes without a husband. While there are unavoidable population issues that make second marriages difficult to obtain for widows, that remarriage is not an outright necessity in many cases.

Ostensibly, the Amish or Amish Mennonite husband is supposed to be equally or more central to family life. He traditionally has the final say in most significant household decisions, tends to family finances, provides order in the rearing of children, and is generally the leader in a patriarchal and patrilocal society. However, the void left by his passing is much less urgently filled. This is very possibly because the basic functions performed by the Plain father - ensuring home stability with money and physical labor-are replaceable in the form of church-based mutual aid. Alms from the deacon or a team of workmen from the church can perform at least some of the husband's tasks. The same economic replacement is simply not true with domestic work. This point is made succinctly by an Amish woman named Katie Smucker, who writes, "A home is not a home unless the [Plain] lady is there making it a home." 42

The Plain churches are quite aware of the reasons for their persistent growth throughout the United States and Canada. They have been perceptive of both obstacles and opportunities for

\footnotetext{
42 Johnson-Weiner, Amish Women, 218.
} 
growth and have often altered standards of practice in response to new trends. ${ }^{43}$ If the past and present informal convention about widow remarriage represented a serious threat to the proper raising of Amish and Amish Mennonite children, it is reasonable to believe church leaders would have encouraged remarriage for both widows and widowers by the time the 2015 and 2019 directories were published.

As mentioned previously, this study is primarily a statistical analysis of widowhood and remarriage in Plain communities. Complete interpretation of the data is not possible without qualitative research and contact with Plain populations. However, the consistency of some of these trends across two centuries and across these two sects is meaningful. Marriage practices among the Plain Anabaptists are important and highly codified, so it is natural that they have been less susceptible to change over time than other practices.

\section{Further Research}

The statistics presented above furnish numerous opportunities for more intensive research work. Though this article's interpretation of the data focused on gender roles, there is much to be written about the retention of young people, choice of suitors in "squeezed" communities, and family life among the blended families of two remarried spouses.

One opportunity for further research is the apparent correlation between family size and mortality. Seifter et al. report a rise in the Amish bereavement effect as family size grows. ${ }^{44}$ Higher numbers of surviving children at the time of spousal death were associated with shorter survival times for the living parent. Data from the 2019 Amish Mennonite cases suggest support for this pattern, as cohorts with more children reliably waited less time to remarry. While increased mortality might not consciously motivate the bereaved to marry quickly, remarriage is linked to an increase in life expectancy among Amish populations. ${ }^{45}$ Additionally, Elmer Lewis Smith reported an average of more than ten children in Amish families with a parent who had died by suicide. ${ }^{46}$ Smith's sample size in this case was quite small, but an average size in these families of roughly double that found in the rest of the population is significant.

Mortality rates in bereaved Amish spouses may be elevated because family networks are not always an effective form of long-term social support. ${ }^{47}$ While recently bereaved spouses tend to initially rely on children and grandchildren, this activity declines over time. Lim-Soh found that spouses avoiding mortality after a partner's passing tend to eventually replace consistent family time with other forms of socializing. ${ }^{48}$ Additionally, rates of non-family social contact were consistently lower if the bereaved spouse had experienced marital satisfaction and economic stability. It is possible that family-oriented, traditional Amish lifestyles may prevent widows from

\footnotetext{
${ }^{43}$ Beachy, Unser Leit, 395-473.

${ }^{44}$ Seifter et al., "Bereavement Effect."

${ }^{45}$ Seifter et al., "Bereavement Effect."

${ }^{46}$ Smith, The Amish Today, 191.

${ }^{47}$ Lim-Soh, "Social Participation in Widowhood."

${ }^{48}$ Lim-Soh, "Social Participation in Widowhood."
} 
finding the right kinds of social contact. This could be supported by data reported by Kozimor, in which Old Order spouses 56-80 years old were 17.2 percent more likely to remarry after three years of bereavement. ${ }^{49}$ It is possible that some sense a waning efficacy of family activities compared to other forms of social life. One could assume that a larger network of grandchildren and relatives would provide the social support necessary to prevent increased post-bereavement mortality. That this may not be the case is worth study.

Also worth investigation are the various forms of social support provided by the Plain community after a spouse's death. General attitudes towards death are likely an aid to surviving spouses in these cases. The Amish can appear stoic about the death of loved ones, at least in public. References to being "called home" and being "in a better place" are common, with many Amish memorial poems referencing an escape from the world's pain. ${ }^{50}$ Similar poems published in Plain publications often refer to a deceased child as fortunate, as their surviving relatives know they are in God's hands. Methods of support during a spouse's mourning period can be diverse and profound despite this hopeful conception of death. These include contact from widows' groups and widow circle letters, personal visits, material aid, labor on the property, and more. Seifter et al.'s report of high mortality as time passes is not comprehensive among bereaved Amish spouses. Some will press on, and it is worth studying the efficacy and gendered differences of social support practices.

This article's discussion is also limited by the nature of the directories used. As they are primarily intended for reference and communication among Anabaptist settlements, the death dates and other details of deceased church members from previous directory editions are not provided. This prevents a review of widowhood from describing potential trends regarding the bereavement effect, the effects of remarriage on mortality, and how family size may influence the two. As these are interesting dynamics given the relative cohesion of Amish communities, information on mortality would be a useful addition to future data sets.

The Amish Mennonite Directory's demographic information allows for a study of Amish Mennonite widowhood from several angles. While informative, such a review is most valuable when compared to previous Plain population studies. Past and present data shows that Plain widowers remarry more often and at a wider age range than widows. It also shows that the presence of children in the home correlates to lower remarriage wait times for men, with little evidence of a similar correlation for bereaved women.

Finally, this data demands an extended and better-researched survey of the construction of Plain gender roles. Such a work could draw from the myriad recent scholarship on the topic, some of which is referenced in this article. Particularly ripe for study are the internally cited reasons for the patriarchal nature of Amish and Amish Mennonite life. The main warrant for male leadership is biblical. The Pauline epistles play an important role in Anabaptist theology, and members of these churches frequently cite the apostle's writings on gender in the church. ${ }^{51}$ Another factor undergirding self-conceptions of gender is the concept of competency. Many Plain women internalize the idea

\footnotetext{
${ }^{49}$ Kozimor, "The Remarriage Interval."

${ }^{50}$ Smith, The Amish Today, 206.

${ }^{51}$ Johnson-Weiner, Amish Women, 28-29.
} 
that men should lead the church and school system out of necessity; women are simply unable to take on the task. ${ }^{52}$ Even those women who have opened their own businesses often show a hesitancy to claim them, instead calling those establishments "family businesses." ${ }^{53}$ Ironically, remarriage data reinforce the suggestion that plenty of Amish women consciously or unconsciously feel that men are less self-sufficient than women, and are unable to proceed without a domestic helper. ${ }^{54}$

Are those decisions somewhat influenced by the availability of single men to widows? Without doubt. Could one credibly claim that Plain husbands only exist to provide money and labor, or that spouses make life decisions based solely on the wishes of their church? Certainly not. Amish and Amish Mennonite society is not that simple. However, viewing widowhood in those communities through a quantitative lens produces research questions demanding more thorough investigation.

\section{Bibliography}

Beachy, Leroy. Unser Leit: The Story of the Amish. 2nd ed. Vol. 2. Millersburg, OH: Goodly Heritage Books, 2015.

Church Directory of the Lancaster County Amish and Outlying Daughter Settlements. Kirkwood, PA: The Diary, 2015.

George, Linda K. "Sociological Perspectives on Life Transitions." Annual Review of Sociology, 19, no. 1 (1993): 353-373. https://doi.org/10.1146/annurev.so.19.080193.002033

Graybill, Beth. "Amish Women, Business Sense: Old Order Women Entrepreneurs in the Lancaster County, Pennsylvania, Tourist Marketplace." PhD diss., University of Maryland, 2009. https://drum.lib.umd.edu/handle/1903/9245/.

Gurrentz, Benjamin, and Yeris Mayol-Garcia. "Love and Loss among Older Adults: Marriage, Divorce, Widowhood Remain Prevalent among Older Populations." United States Census Bureau, May 26, 2021. https://www.census.gov/library/stories/2021/04/love-and-lossamong-older-adults.html.

Handrick, Frances M. "Amish Women: Work and Change-An Investigation into the Lives of Amish Women in Pennsylvania and Ohio.” PhD diss., University of Birmingham, 2019. https://etheses.bham.ac.uk//id/eprint/9575/1/Handrick2019PhD.pdf.

Hostetler, John A., ed. Amish Roots: A Treasure of History, Wisdom and Lore. Baltimore: Johns Hopkins University Press, 1992.

Hostetler, John A. Amish Society. 4th ed. Baltimore: Johns Hopkins University Press, 1993.

Hurst, Charles, and David McConnell. An Amish Paradox: Diversity and Change in the World's Largest Amish Community. Baltimore: Johns Hopkins University Press, 2010.

Jellison, Katherine. "Content Overview for This Special Issue." Journal of Amish and Plain Anabaptist Studies 8, no. 2 (2020): 107-108.

https://ideaexchange.uakron.edu/amishstudies/vol8/iss2/2/.

\footnotetext{
${ }^{52}$ Johnson-Weiner, Amish Women, 93-102.

${ }^{53}$ Johnson-Weiner, Amish Women, 170.

${ }^{54}$ Johnson-Weiner, Amish Women, 151.
} 
Johnson-Weiner, Karen. The Lives of Amish Women. Baltimore: Johns Hopkins University Press, 2020.

Jolly, Natalie. "Hemmed In? Considering the Complexities of Amish Womanhood." Journal of Amish and Plain Anabaptist Studies 8, no. 2 (2020): 159-168.

https://ideaexchange.uakron.edu/amishstudies/vol8/iss2/7/.

Kollmorgen, Walter M. Culture of a Contemporary Rural Community: The Old Order Amish of Lancaster County, Pennsylvania. Washington, DC: Bureau of Agricultural Economics, 1942.

Kozimor, Michele. L. "The Remarriage Interval of the Old Order Amish of the Lancaster County Settlement." Paper presented at Three Hundred Years of Persistence and Change: Amish Society 1693-1993 (An International Conference), Elizabethtown, PA, July 1993.

Kraybill, Donald B. The Riddle of Amish Culture. Rev. ed. Baltimore: Johns Hopkins University Press, 2001.

Lim-Soh, Jeremy W. "Social Participation in Widowhood: Evidence from a 12-Year Panel." Journals of Gerontology: Series B, 2021. https://doi.org/10.1093/geronb/gbab072

McCallister, Pat, and Carol Michael. "Old Order Amish Widowers: Widowers or Remarriage." Paper presented at Amish in America: A Multidisciplinary Conference, Elizabethtown, PA, June 2007.

Miller, DeVon, and Mabel Miller. Amish Mennonite Directory, 2019. Millersburg, OH: Abana Books, 2019.

Schmidt, Kimberly, Diane Zimmerman Umble, and Steven Reschly. Strangers at Home: Amish and Mennonite Women in History. Baltimore: Johns Hopkins University Press, 2002.

Schreiber, William. Our Amish Neighbors. Chicago: University of Chicago Press, 1962.

Seifter, Ari, Sarabdeep Singh, Patrick F. McArdle, Kathleen A. Ryan, Alan R. Shuldiner, Braxton D. Mitchell, and Alejandro A. Schäffer. "Analysis of the Bereavement Effect after the Death of a Spouse in the Amish: A Population-Based Retrospective Cohort Study." BMJ Open 4, no. 1 (2014). https://doi.org/10.1136/bmjopen-2013-003670

Smith, Elmer Lewis. The Amish Today: An Analysis of Their Beliefs, Behavior, and Contemporary Problems. Allentown, PA: Pennsylvania German Folklore Society, 1961.

Stevenson, J. C., P. M. Everson, and M. H. Crawford. "Changes in Completed Family Size and Reproductive Span in Anabaptist Populations.” Human Biology 61, no. 1 (1989): 99-115. http://www.jstor.org/stable/41464105.

Thalheimer, Steve. "A Little More in the World: Why Amish Parents Choose to Send Their Children to Public Schools." Journal of Amish and Plain Anabaptist Studies 9, no 1 (2021): 27-54. https://ideaex change.uakron.edu/amishstudies/vo19/iss1/4/.

Troyer, Henry. "Change and Continuity in Amish Wedding Dates in the Holmes County, Ohio, Settlement." Journal of Plain Anabaptist Communities 1, no. 2 (2021): 95-103. https://doi.org/10.18061/jpac.v1i2.7948

Young Center for Anabaptist and Pietist Studies. "Amish Population Profile, 2020." Amish Studies, 2020. http://groups.etown.edu/amishstudies/statistics/amish-population-profile-2020/. 